Natural Hazards and Earth System Sciences, 6, 55-61, 2006

SRef-ID: 1684-9981/nhess/2006-6-55

European Geosciences Union

(C) 2006 Author(s). This work is licensed

under a Creative Commons License.

\title{
Investigation and monitoring in support of the structural mitigation of large slow moving landslides: an example from Ca' Lita (Northern Apennines, Reggio Emilia, Italy)
}

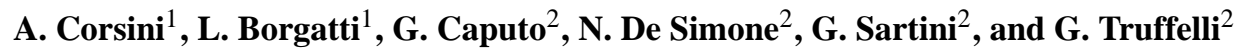 \\ ${ }^{1}$ Dipartimento di Scienze della Terra, Università di Modena e Reggio Emilia, Largo S. Eufemia, 19, 41100 Modena, Italy \\ ${ }^{2}$ Regione Emilia Romagna, Servizio Tecnico Bacini Enza e sinistra Secchia, Via Emilia S. Stefano, 25, 42100 Reggio Emilia, \\ Italy
}

Received: 1 August 2005 - Revised: 23 November 2005 - Accepted: 23 November 2005 - Published: 16 January 2006

Part of Special Issue "Documentation and monitoring of landslides and debris flows for mathematical modelling and design of mitigation measures"

\begin{abstract}
The Ca' Lita landslide is a large and deep-seated mass movement located in the Secchia River Valley, in the sector of the Northern Apennines falling into Reggio Emilia Province, about $70 \mathrm{~km}$ west of Bologna (Northern Italy). It consists of a composite landslide system that affects Cretaceous to Eocene flysch rock masses and chaotic complexes. Many of the components making up the landslide system have resumed activity between 2002 and 2004, and are now threatening some hamlets and an important road serving the upper watershed area of River Secchia, where many villages and key industrial facilities are located.

This paper presents the analysis and the quantification of displacement rates and depths of the mass movements, based on geological and geomorphological surveys, differential DEM analysis, interpretation of underground stratigraphic and monitoring data collected during the investigation campaign that has been undertaken in order to design cost-effective mitigation structures, and that has been conducted with the joint collaboration between public offices and research institutes.
\end{abstract}

\section{Introduction}

The Ca' Lita landslide is a complex and composite rototraslational rock slide-earth flow (WP/WLI 1993; Cruden and Varnes, 1996) affecting Cretaceous to Eocene flysch rock masses and chaotic complexes (Regione Emilia-Romagna, 1982), that can be classified as overconsolidated weak rocks (sensu Bieniawski, 1989), with a marked lithological and structural complexity (A.G.I., 1985). It is located in the Secchia River Valley, in the sector of the Northern Apennines falling into Reggio Emilia Province, Northern Italy (Fig. 1).

Correspondence to: A. Corsini

(corsini.alessandro@unimore.it)
The landslide resumed activity in 2002 and since then has alternated surge phases (like in winter 2003 and, in particular, early spring 2004) and periods of almost suspended movements (generally summer). The style of movement (Cruden and Varnes, 1996) of the landslide in the period spanning from 2002 to 2004 was retrogressive in the upper part, advancing in the mid-lower part, and partially widening on flanks. Mass movements reached peak velocities of about $10 \mathrm{~m}$ per day at the toe, while in the source area, rotational rock slides and traslational earth slides evolved at velocities of cm-dm per day. Locally, quite superficial mudflows, or collapses of the rockslide front, moved as fast as metres per hour.

At present, August 2005, the landslide extends from an elevation of $650 \mathrm{~m}$ at the crown to $230 \mathrm{~m}$ at the tip. Its total track length is approximately $3 \mathrm{~km}$ and its maximum width is about $1.4 \mathrm{~km}$ in the rear scarp area, with a maximum depth of about $50 \mathrm{~m}$ in the upper part (Fig. 1). During 2002-2004 period the toe of the landslide has advanced for more than $400 \mathrm{~m}$ over a slope angle of about $10^{\circ}$, causing the filling of the local valley with a $30 \mathrm{~m}$ thick deposit. It has been estimated, on the basis of DEMs comparison, that the reactivation events between 2002 and 2004 have mobilised something like twenty millions cubic meters of mixed clays and boulders (Borgatti et al., 2006).

The reactivation of the $\mathrm{Ca}$ ' Lita landslide caused particular concern to civil protection authorities for the possible interruption of road connection to the upper Secchia River basin caused by the advancement of the landslide toe and for the possible involvement of some hamlets located at the crown due to retrogressive sliding. During the most critical weeks, excavators worked for controlling the advancement of the front of the landslides on a $24 \mathrm{~h}$ shift basis, while technicians kept under constant visual control the retrogressive phenomena at the crown. After-emergency interventions 


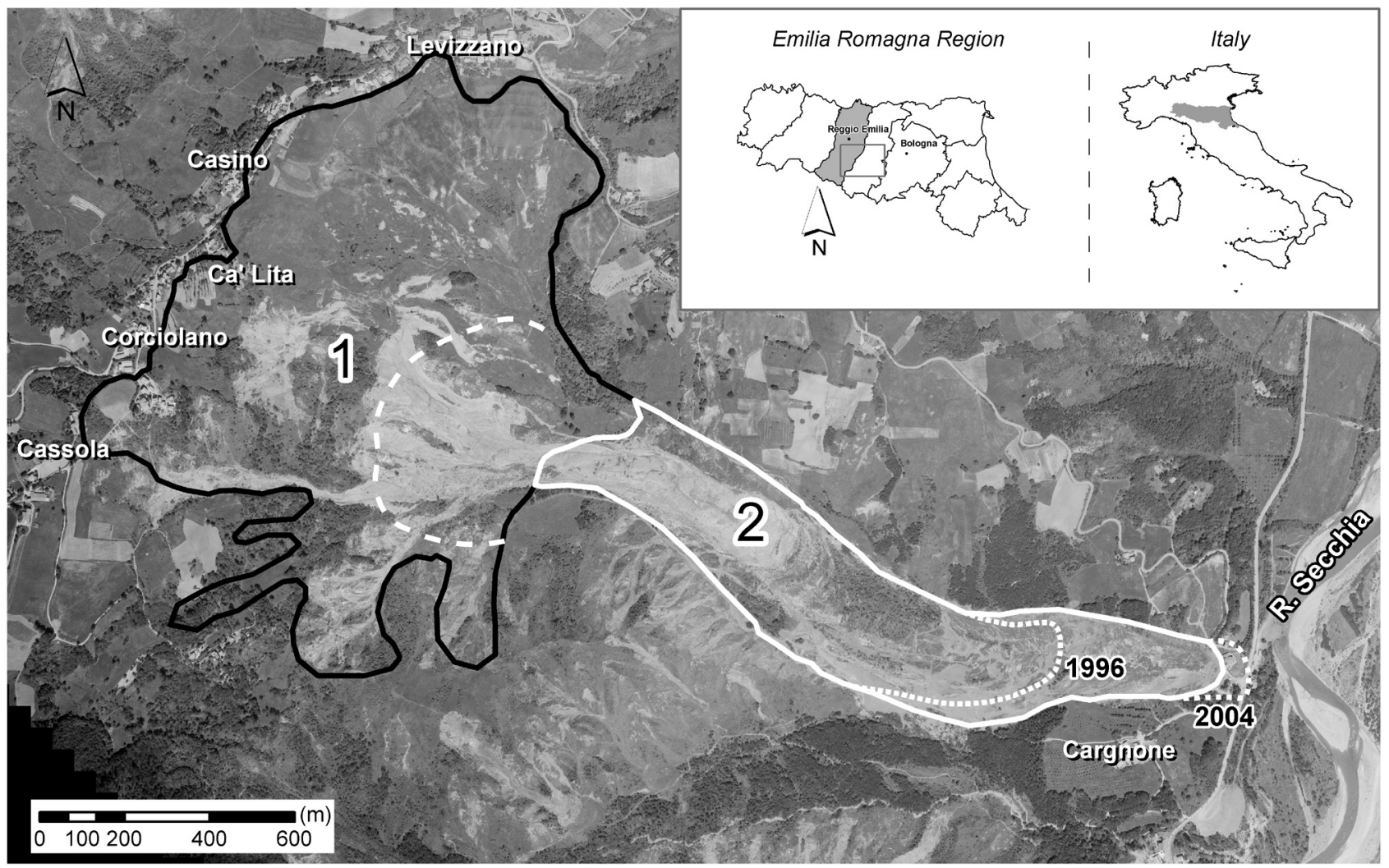

Fig. 1. Geographical location of the study site and sketch of the two distinct phenomena that make up the Ca' Lita landslide. 1: Rotational and - translational rock slides - earth slides. 2: Earth slides-earth flows. Broken white line: main scarp of the earth slide-earth flow. Dotted white lines: tip of the landslide deposits in 1996 and during the emergency phase of 2004.

have mainly consisted in the re-arrangement of material on the landslide body and reshaping of the topographic surface, carried out in order to seal fissures and cracks and to avoid the formation of water impoundments in reverse-slope situations. Also surface drainage networks were restored, mainly through the creation of diversion ditches. A few months after the emergency, an investigation and monitoring campaign aimed at collecting relevant data for the design of structural mitigation measures was started.

The complexity and large dimension of landslide make its structural mitigation a very serious problem. However, the "do nothing" option, that is often preferable for such large phenomena, is not a viable one in this case. This is because the relocation of the private properties endangered by the phenomenon would have to consider, also, indirect social aspects and costs, and that the deviation to an alternative route of the principal road at the bottom of the slope would only be possible if a massive economic effort was put into bridging it over the contiguous Secchia riverbed. Therefore, a structural mitigation action had to be undertaken, being conscious of technical difficulties and uncertainties regarding its success.

The general approach to the structural mitigation of the Ca' Lita landslide arose from previous experiences on similar phenomena in the area, and is based on few simple principles: restore an efficient surface drainage pattern; create a deep-drainage system by means of pits and sub-horizontal drains, protect the deep drainage systems for the time needed for them to actually have a stabilisation effect on the slope by means of deep-founded anchored pile walls. This type of approach was applied in key critical sectors of the landslide, that were identified by direct observation of the landslide evolution mechanisms and detailed field survey supported also by high definition DEMs produced with an airborne LiDAR survey. As previously mentioned, in these sectors of the landslide, preparatory geotechnical investigation and monitoring has been carried out in order to evaluate the feasibility of certain mitigation structures and to support their technical design.

\section{Preparatory geotechnical investigation and monitor- ing in critical areas}

The landslide, classified as a complex and composite phenomenon (WP/WLI 1993; Cruden and Varnes, 1996), can be subdivided into two main phenomena, one affecting the upper slope and the other the medium to lower slope (Fig. 1).

The uppermost phenomenon takes place in relation to a general processes of rock block sliding affecting flysch rock masses. In this area, rotational and traslational rock slides take place and, in many cases, evolve into earth slides or mud flows (Hungr et al., 2001). In particular, in the southern sector a more than $100 \mathrm{~m}$ thick flysch slab is dipping upslope 


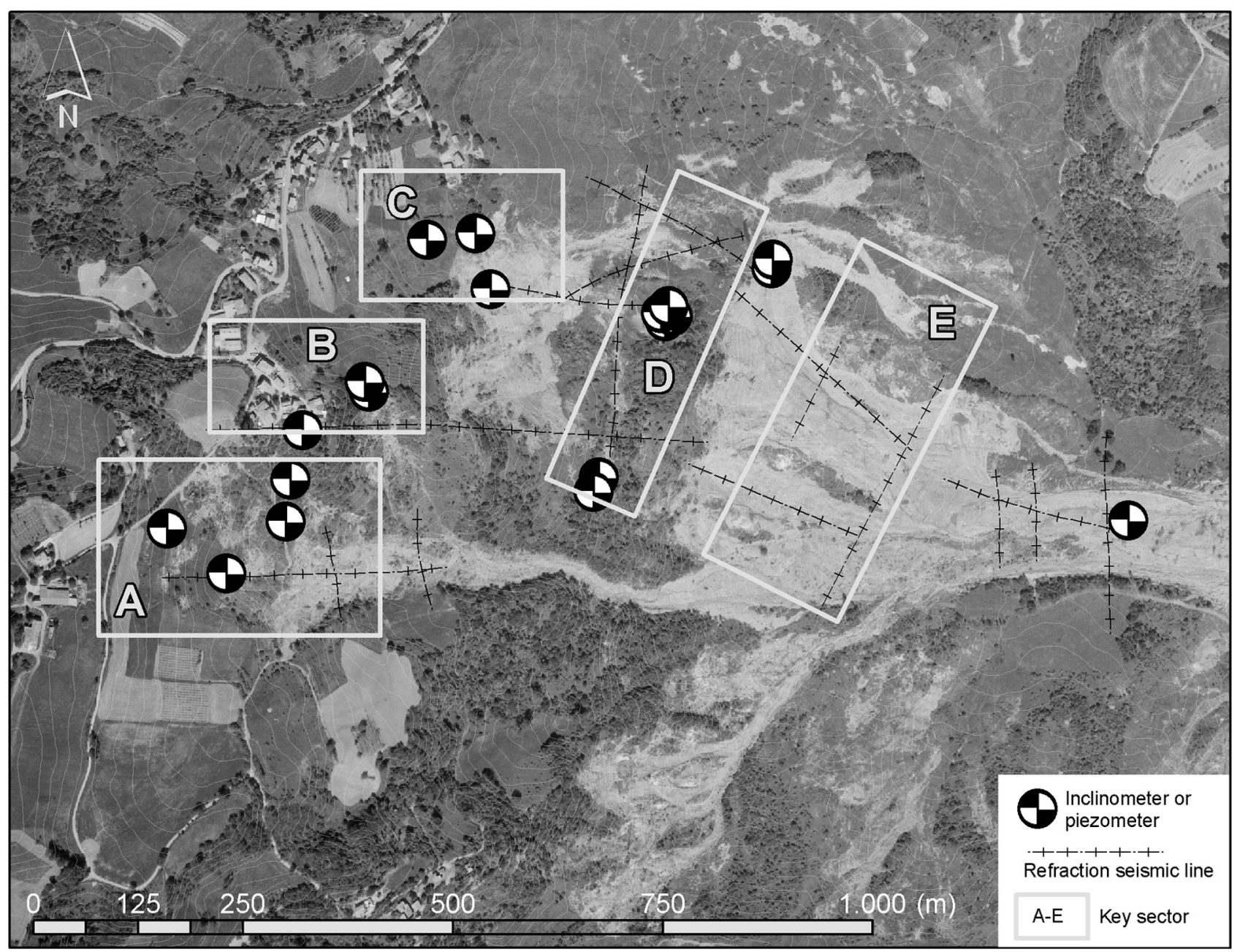

Fig. 2. Key areas selected for investigation and monitoring (A-E) and location of instrumented boreholes and refraction seismic lines.

Table 1. Description of the Ca' Lita landslide system critical areas. Legend: Geological Units: MOH3 - Monghidoro Fm., Flysch; VRO Val Rossenna Clays Fm., clayey chaotic complex; MVR2a - Val Rossenna Mélanges Fm., clayey chaotic complex. Attitude: up = upslope; do $=$ downslope. Way-up: ur $=$ upright; ov $=$ overturned. $*=$ measured ${ }^{\circ}=$ estimated. In sector B no displacements have been detected up to date.

\begin{tabular}{|c|c|c|c|c|c|}
\hline \multirow{2}{*}{$\begin{array}{l}\text { Slope movements } \\
\text { characteristics }\end{array}$} & \multicolumn{5}{|c|}{ Investigation and monitoring areas } \\
\hline & A - Cassola & B - Corciolano & C-Ca' Lita & D - Piana & E - Colata \\
\hline Type of movement & $\begin{array}{l}\text { Roto-transl. } \\
\text { earth slides }\end{array}$ & $\begin{array}{l}\text { Roto-transl. } \\
\text { rock slides }\end{array}$ & $\begin{array}{l}\text { Roto-trans. } \\
\text { earth slides }\end{array}$ & $\begin{array}{l}\text { Roto-transl. rock } \\
\text { slides - earth slides }\end{array}$ & $\begin{array}{l}\text { Translational earth } \\
\text { slides - flows }\end{array}$ \\
\hline Affected bedrock & $\begin{array}{l}\text { MOH3 (up/ov), } \\
\text { MVR2a (up/ov) }\end{array}$ & MOH3 (up/ov) & $\begin{array}{ll}\text { MOH3 } \\
\text { (up/ov) }\end{array} \quad$ (do/ur) $\quad+$ & MOH3 (up/ov) & $\begin{array}{l}\text { MVR2a (up/ov), } \\
\text { MOH3 (do/ur), VRO } \\
\text { (do/ur) }\end{array}$ \\
\hline Landslide material & Clay, silt, blocks & $\begin{array}{l}\text { Disarranged } \\
\text { masses }\end{array}$ & Clay, silt, blocks & $\begin{array}{l}\text { Clay, silt, blocks }+ \\
\text { dismembered rock } \\
\text { masses }\end{array}$ & $\begin{array}{l}\text { Clay, silt }+ \text { blocks in } \\
\text { the upper meters }\end{array}$ \\
\hline Total thickness & $10-25(\mathrm{~m})$ & - & $20(\mathrm{~m})$ & $45(\mathrm{~m})$ & $15(\mathrm{~m})$ \\
\hline Depth of sliding & 5 and $20^{*}(\mathrm{~m})$ & - & $15 *(\mathrm{~m})$ & $43^{*}$ and $20^{*}(\mathrm{~m})$ & $9 *(\mathrm{~m})$ \\
\hline Min. displacement rate & $\mathrm{cm} / \mathrm{month}^{*}$ & - & $\mathrm{cm} / \mathrm{month}^{*}$ & $\mathrm{~cm} / \mathrm{month}^{*}$ & $\mathrm{dm}$ to $\mathrm{m} / \mathrm{month}^{*}$ \\
\hline Max. displacement rate & $\mathrm{dm} / \mathrm{day}^{\circ}$ & - & $\mathrm{dm} /$ day $^{\circ}$ & $\mathrm{dm} / \mathrm{day}^{\circ}$ & $\mathrm{m} / \mathrm{day}^{\circ}$ \\
\hline Groundwater depth & $2-6^{*}(\mathrm{~m})$ & $17-18^{*}(\mathrm{~m})$ & $8-2 *(m)$ & $10-25 *(\mathrm{~m})$ & $1-8^{*}(\mathrm{~m})$ \\
\hline
\end{tabular}



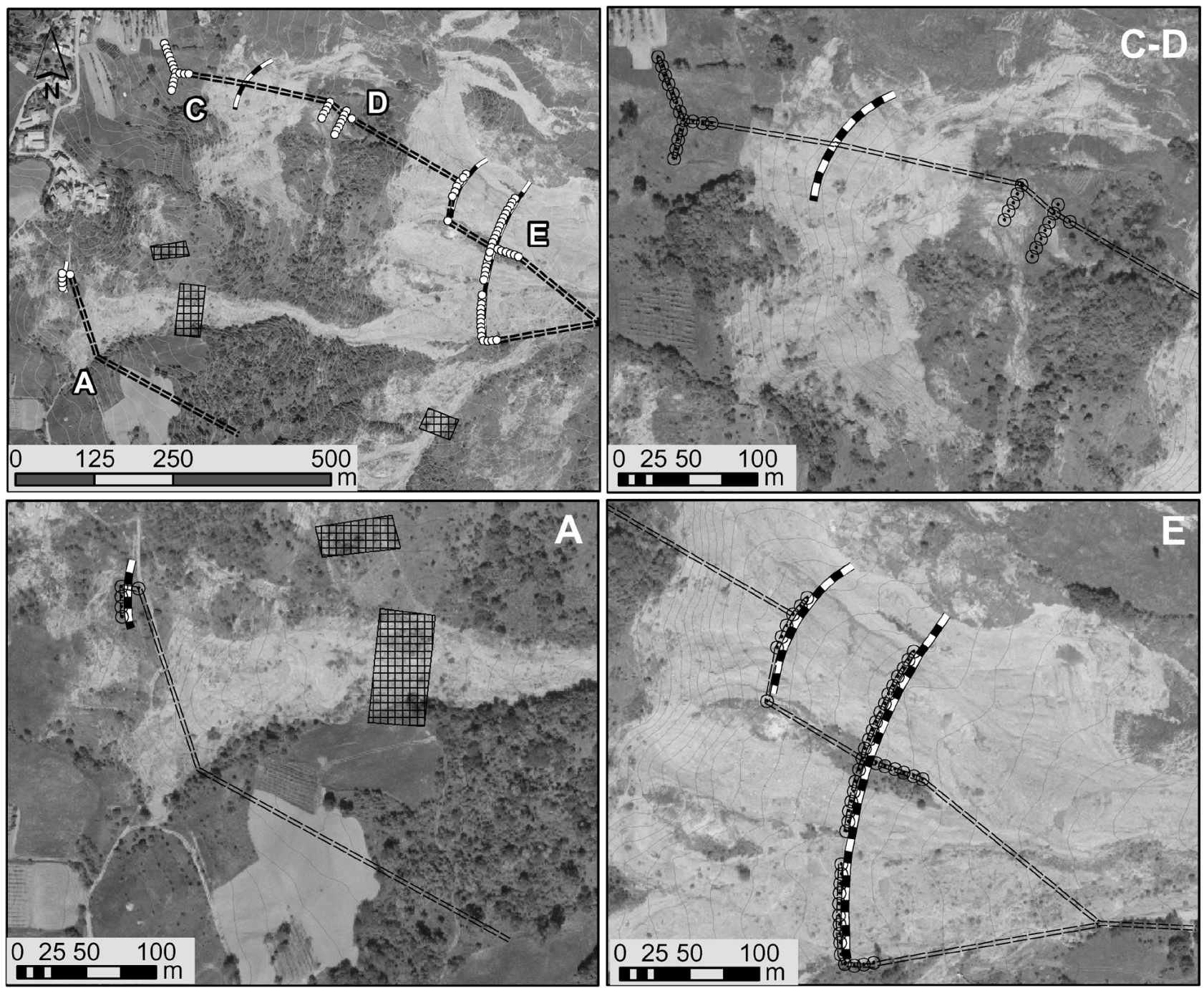

Legend

Draining ditch

$\odot \odot \odot$ Shield of drainage wells

Retaining wall

Fig. 3. Sketch of the structural mitigation measures built in the key areas A, C, D and E since spring 2005.

and overlays the basal clayey chaotic complexes. This causes a stiffness contrast that, in conjunction with the presence of pervasive structural discontinuities, causes the sliding of huge rock blocks that, at the surface, is evidenced by a series of trenches located in the crest leading to Corciolano.

The lowermost phenomenon is essentially a rotational earth slide - earth flow affecting the degradated part of clayey complexes and debris material coming from the uppermost phenomenon. Large part of its primary detachment scarp is buried by the debris material convoyed into the source area of the lower landslide by the retrogression of the marginal portion of the flysch slab undergoing deep sliding, and by other very frequent mud flows and earth flows triggered in the uppermost landslide area.

The preparatory underground investigation and monitoring campaign was principally aimed to: define landslide thickness and bedrock depth (by seismic surveys and boreholes); define geotechnical properties of the landslide mass (by core sampling, laboratory analysis and permeability tests on boreholes); estimate movements rate and depth (inclinometers and TDR cables, wire extensometers); define groundwater level fluctuation range and timing with respect to rainfall and acceleration of movements (piezometers with electric transponders).

Altogether, the investigation and monitoring campaign consisted of (Fig. 2): a new aerial photo coverage at 1:14000; a detailed landslide map at 1:5000 scale; $88 \mathrm{~mm}$ cores of landslide masses and bedrock from 16 boreholes, 40 to $90 \mathrm{~m}$ deep; a set of monitoring data obtained from 9 inclinometer casings, 2 Time Domain Reflectometer cables (TDR) of $41.3 \mathrm{~mm}$ diameter, 2 extensometers and 6 piezometers, some of which equipped with electric pressure transducers and data-loggers for continuous acquisition; refraction seismic on 16 cross and longitudinal sections, elaborated with tomography techniques. 
Table 2. Specifications of mitigation intervention in the key sectors.

\begin{tabular}{|c|c|c|c|c|}
\hline \multirow{2}{*}{ Draining wells specifications } & \multicolumn{4}{|c|}{ Structural intervention areas } \\
\hline & A - Shield Cassola & C - Shield Ca' Lita & D - Shield Piana & E - Shield Colata \\
\hline no. of wells in the shield & 4 & 15 & 12 & 20 \\
\hline Depth $(\mathrm{m})$ & $9.0 \div 10.0$ & $13.0 \div 20.0$ & 30.0 & $8.0 \div 10.5$ \\
\hline Diameter (m) & 1.2 & $1.2 \div 1.5$ & $1.2 \div 1.5$ & 1.2 \\
\hline Average distance between wells (m) & 7.0 & 7.0 & 7.0 & 7.0 \\
\hline Depth of the low-level collector (m) & $-7.5 \div-8.5$ & $-11.5 \div-18.50$ & -28.50 & $-6.5 \div-9.0$ \\
\hline Diameter of the low-level collector (mm) & 86 & 86 & 86 & 86 \\
\hline Internal diameter of the discharge collector $(\mathrm{mm})$ & $120-136$ & $120-136$ & $120-136$ & $120-136$ \\
\hline Pumping & Gravity flow & Gravity flow & Gravity flow & Gravity flow \\
\hline \multirow{2}{*}{ Retaining walls specifications } & \multicolumn{4}{|c|}{ Structural intervention areas } \\
\hline & A - Wall Cassola & C - Wall Ca' Lita & D - Wall Piana & E - Wall Colata \\
\hline Length (m) & 48.50 & 97.5 & 118.9 & 292.5 \\
\hline Height of the kerb (m) & 1.0 & 1.0 & 1.0 & 1.0 \\
\hline Height of the wall (m) & 2.0 & 2.0 & 2.0 & 2.0 \\
\hline Thickness of the kerb (m) & 1.5 & 1.5 & 2.6 & 2.6 \\
\hline Thickness of the wall (m) & 0.40 & 40 & 50 & 50 \\
\hline Depth of piles (m) & $7.3-11.3$ & 11.3 & $9.3-11.3$ & 11.3 \\
\hline Diameter of piles (mm) & 1000 & 1000 & 1000 & 1000 \\
\hline No. of piles & 30 & 40 & 72 & 232 \\
\hline Anchors & five $75 \mathrm{t}$ strands & five $75 \mathrm{t}$ strands & five $75 \mathrm{t}$ strands & five $75 \mathrm{t}$ strands \\
\hline Length of anchors (m) & 25.0 & 25.0 & 25.0 & 25.0 \\
\hline No. of anchors & 10 & 22 & 44 & 112 \\
\hline Diameter of anchors core (mm) & 150 & 150 & 150 & 150 \\
\hline Pre-tensioning/tensioning $(\mathrm{t})$ & $40-50$ & $40-50$ & $40-50$ & $40-50$ \\
\hline Inclinometers & - & - & 1 & 3 \\
\hline Pressure gauge & 1 & 2 & 2 & $3-4$ \\
\hline
\end{tabular}

This extensive set of information was needed in order to answer some key questions such as: is bedrock shallow enough to have piles firmly drilled into it?, can the water table be intercepted and significantly lowered by deep drainage pits?, is the sliding surface at a depth that intercepts the pits, hence risking to cut them?, is the movement rate at present days low enough to allow pits and piles for the sustaining structures to be drilled and kept stable until anchors bulbs can be tensed and drainages make effect?, and so on.

This interpretation of slope failure mechanisms, together with the evidence collected during the recent reactivation events and other specific analyses (see Borgatti et al., 2006), was the basis on which the main critical zones of the landslide were selected for investigation and monitoring. These are indicated as A to E in Fig. 2.

The relevant results obtained in the different key zones are summarised in Table 1.

On the basis of the surveys and monitoring data so far collected, it is believed that the mechanisms and times of reactivation of the landslides are governed by the hydrogeological setting of the study area and, in particular, by a circuit of groundwater directed from the uppermost slab into the lowermost clays, in which the sliding surfaces develop. Concerning groundwater circulation, the area display numerous small springs with seasonal discharge that lie in correspon- dence with permeability boundaries between the flysch slab and the clayey substratum, which by now is covered by a thick debris deposit. The depletion zone of the upper landslide acts as a basin, that keeps the debris in a saturated state, thus promoting movements especially in occasion of intense and/or prolonged rainfall or rapid snowmelt, that are the conditions occurred before the main reactivation events. Starting from these premises, the mitigation strategy has been designed with the principal aim to lower the groundwater level at the slope scale.

\section{Structural mitigation measures}

Starting from the spring 2005, permanent structural consolidation works (Holtz and Schuster, 1996) have been carried out in four of the five key areas described beforehand. Structural mitigation is based on various types of draining structures, such as groins and draining wells that have also a structural function. The drainage systems are coupled with retaining walls founded on piles that are meant to ensure their stability for the time needed to become significantly efficient (Fig. 3, Table 2). In a few other areas earth dams have been built to act as barriers on specific flow fronts.

At all the four intervention locations, subsurface drainage is guaranteed by sets of large diameter vertical wells drilled 

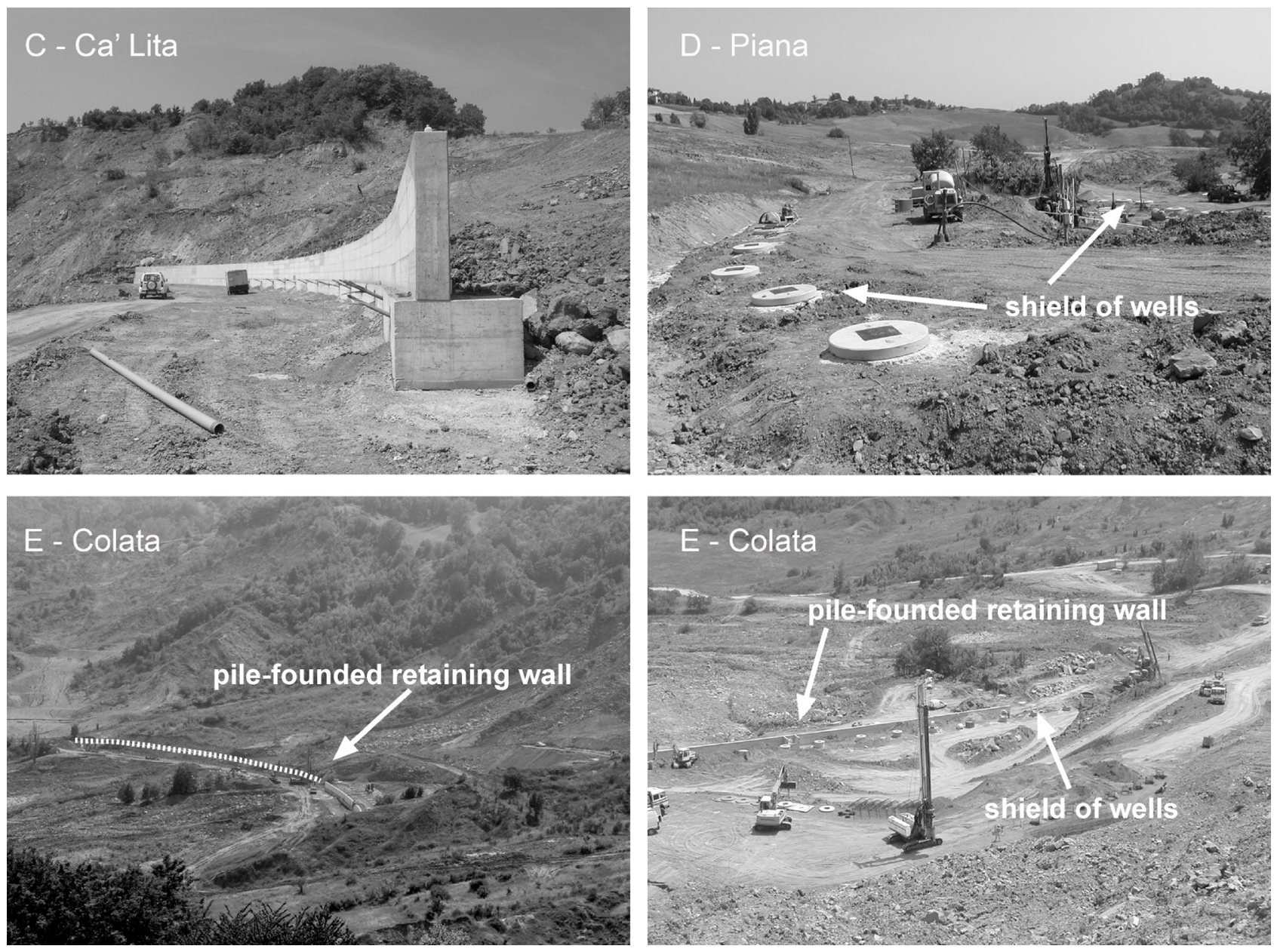

Fig. 4. Structural mitigation measures built in the key areas C, D and E since spring 2005.

closely one another, in order to create a sort of drainage front. Each well is connected to its neighbour at the bottom by horizontal drains. These systems normally drain by means of gravity flow; however, during construction phases pumps have been used temporarily in order to remove water from low-level collector galleries for example in case of intense rainfalls. Generally, in the apenninic setting the major drawback of draining works is due to the low permeability of landslide materials. In this specific case, some pumping tests carried out during December 2004 in $16 \mathrm{~m}$ deep exploratory pits, have allowed a yield of the highly disarranged sliding flysch masses in the order of $61 / \mathrm{s}$ to be estimated, that indicates a high trasmissivity of the rock masses. The good hydraulic response of the landslide deposits ensures the efficiency of the designed measures. In any case, the expected maximum efficiency is generally achieved only months after the implementation of the system, whereas in the meanwhile the extent of displacements could seriously compromise the draining system itself. For this reason, in all the intervention locations, the shields of drainage wells have been designed coupled with structural retention systems located downslope, that are funded on piles and anchored to the bedrock. In particular, these reinforced concrete wall are founded on bored- in place not contiguous pile shields. The reinforcement is guaranteed by tied-back anchors that are installed and tensioned against the face of the wall. The wall acts partially as a retention structure, but in particular is a large reaction plate for rock anchors, that distribute the anchor loads into the rock mass (Fig. 4).

It is clear that this kind of semi-rigid structures might suffer damages under the active pressure of the moving mass. For this reason, in the area E, it has been kept close to the top of the lobe, taking also advantage of the shallow location of bedrock, that in this sector is not deeper than 9-10 m and is outcropping in ridges that have been partially buried by the upper landslide debris. It is clear that the effectiveness of this structures can be minimized in case of new massive input of materials from the upper part of the slope, related to large collapses of the rock slide front or new mudflows, that might cause them to be buried under meters of debris. In conclusion, it must be stressed that the main function of these structures is to guarantee the protection of the draining wells as much as possible and not to operate as an actual retention system, that considering the depth of the sliding surfaces and the height of the active landslide scarps, would be definitely underestimated. 
One of the key issues is to carry away from the slope the water drained by the wells and collected by the outlet drains, in order to promote a rapid runoff and improve slope stability. For this purpose, an adequate pattern of diversion ditches and collectors have been designed to convey the water to the streams that border the landslide body.

\section{Conclusions and perspectives}

On the basis of the surveys and of the investigation and monitoring data so far collected, it is believed that the mechanisms and the evolution of the landslide are driven by the geological and structural features, together with the hydrogeological setting of the study area and, in particular, by a circuit of groundwater directed from the uppermost slab into the lowermost clays, in which the deeper sliding surfaces develop. Concerning groundwater circulation, the area display numerous small springs lying in correspondence with permeability boundaries between the flysch slab and the clayey substratum, which by now is covered by thick debris deposits. The depletion zone of the landslide unit acts as a basin that keeps the debris in a saturated state, promoting significant movements directly connected with severe meteo-climatic events.

The investigation and monitoring data presented in this paper have been the basis on which to plan and engineer mitigation measures and strategies and then to check for their efficiency. In the first emergency phase, the consolidation works have consisted in the re-arrangement of displaced materials, in order to avoid the formation of water impoundments and to restore drainage networks. Permanent consolidation works consist of draining trenches, check dams, draining wells and sub-horizontal drains. Structural works and containment structures have also been built over pile foundations reaching the bedrock at 10 to $15 \mathrm{~m}$ of depth, in order to protect drainage systems.

Owing to the dimensions and lithological characteristics of the landslide, it is very difficult to achieve definitive consolidation at reasonable costs, if compared to the intrinsic value of the buildings and structures subject to risk. Indeed, the relationship between landslides and urban development in the Northern Apennines is a problem that cannot definitely be unravelled. The development of many inhabited centres has often taken place in conditions of precarious slope stability, since in many cases definitely safe areas or possible alternatives were not available. In other cases, the presence of large, dormant landslides with wide and flat accumulation zones has allowed the development of many villages since ancient times (Bertolini and Pellegrini, 2001). For this reason, an investment of a total amount of 3000000 EUR been considered affordable and "politically" sustainable by the public boards.

The Ca' Lita landslide reactivation case history is a noticeable example of the possible evolution of landslides involving weak rock masses in an apenninic setting. Case studies such as the Ca' Lita landslide should in fact be analysed in detail, so to provide a complete case history, also thanks to the relatively fast development undergone by the phenomenon, essential for the understanding of landsliding mechanisms and for the planning of a correct and durable mitigation and consolidation action.

Acknowledgements. Geognostic and monitoring data have been collected by Servizio Tecnico dei Bacini Enza e sinistra Secchia of Regione Emilia-Romagna, in the frame of the Intervention Plan supported by Ordinanza del Presidente del Consiglio dei Ministri n. 3357/2004 and Decreto del Presidente del Consiglio dei Ministri 08/07/2004 concerning "Movimenti franosi verificatesi nei Comuni di Baiso e Canossa nel febbraio 2004". Distinct contribution of authors: L. Borgatti and A. Corsini have conceived and written the paper, and have elaborated most of the figures and tables. G. Caputo, N. De Simone, G. Sartini and G. Truffelli have planned and managed geognostic investigation, monitoring campaigns and the design and building of mitigation measures.

Edited by: G. Lollino

Reviewed by: one referee

\section{References}

A.G.I.: Associazione Geotecnica Italiana: Geological outline of Italy: bearing of the geological features on the geotechnical characterization on the example of some typical formations, in: Geotechnical Engineering in Italy, edited by: A.G.I., Tip. L. Chiovini, Roma, 159-184, 1985.

Bertolini, G. and Pellegrini, M.: The landslides of Emilia Apennines (northern Italy) with reference to those which resumed activity in the 1994-1999 period and required Civil Protection interventions, in: Le frane della Regione Emilia-Romagna, oggetto di interventi di Protezione Civile nel periodo 1994-1999, edited by: Bertolini, G., Pellegrini, M., and Tosatti G., Quaderni di Geologia Applicata, 8, 27-74, 2001.

Bieniawski, Z. T.: Engineering rock mass classification, Wiley Interscience Publ., New York, 1989.

Borgatti, L., Corsini, A., Barbieri, M., Sartini, G., Truffelli, G., Caputo, G., and Puglisi, C.: Active large-scale slow moving landslides in weak rock masses: a remarkable example from the Northern Apennines (Italy), Landslides, in press, 2006.

Cruden, D. M. and Varnes, D. J.: Landslides Types and Processes, in: Landslides: Investigation and Mitigation, edited by: Turner A. K. and Schuster R. L., Transportation Research Board, Special Report 247, National Academy Press, Washington D.C., 36-75, 1996.

Holtz, R. D. and Schuster, R. L.: Stabilization of soil slope, in: Landslides: Investigation and Mitigation, edited by: Turner A. K. and Schuster R. L., Transportation Research Board, Special Report 247, National Academy Press, Washington D.C., 439473, 1996.

Hungr, O., Evans, S. G., Bovis, M. J., and Hutchinson, J. N.: A review of the classification of landslides of the flow type, Environmental and Engineering Geoscience, 7, 221-238, 2001.

Regione Emilia-Romagna: Carta geologica dell'Appennino emiliano-romagnolo 1: 10.000. Resp. Pignone R., Ed. SELCA, Firenze, 1982.

WP/WLI - Working Party on the World Landslide Inventory \& Canadian Geotechnical Society: Multilingual Landslide Glossary, BiTech Publishers, Richmond, B.C., 1993. 